

\title{
Football injuries during serie a season 2009-2010
}

Autor(es): $\quad$ Francioni, F. M.; Tessitore, A.

Publicado por: Imprensa da Universidade de Coimbra

URL

persistente: URI:http://hdl.handle.net/10316.2/3380

DOI: $\quad$ DOI:http://dx.doi.org/10.14195/2182-7087_2_16

Accessed : $\quad$ 26-Apr-2023 15:03:16

A navegação consulta e descarregamento dos títulos inseridos nas Bibliotecas Digitais UC Digitalis, UC Pombalina e UC Impactum, pressupõem a aceitação plena e sem reservas dos Termos e Condições de Uso destas Bibliotecas Digitais, disponíveis em https://digitalis.uc.pt/pt-pt/termos.

Conforme exposto nos referidos Termos e Condições de Uso, o descarregamento de títulos de acesso restrito requer uma licença válida de autorização devendo o utilizador aceder ao(s) documento(s) a partir de um endereço de IP da instituição detentora da supramencionada licença.

Ao utilizador é apenas permitido o descarregamento para uso pessoal, pelo que o emprego do(s) título(s) descarregado(s) para outro fim, designadamente comercial, carece de autorização do respetivo autor ou editor da obra.

Na medida em que todas as obras da UC Digitalis se encontram protegidas pelo Código do Direito de Autor e Direitos Conexos e demais legislação aplicável, toda a cópia, parcial ou total, deste documento, nos casos em que é legalmente admitida, deverá conter ou fazer-se acompanhar por este aviso. 
(2) 2011

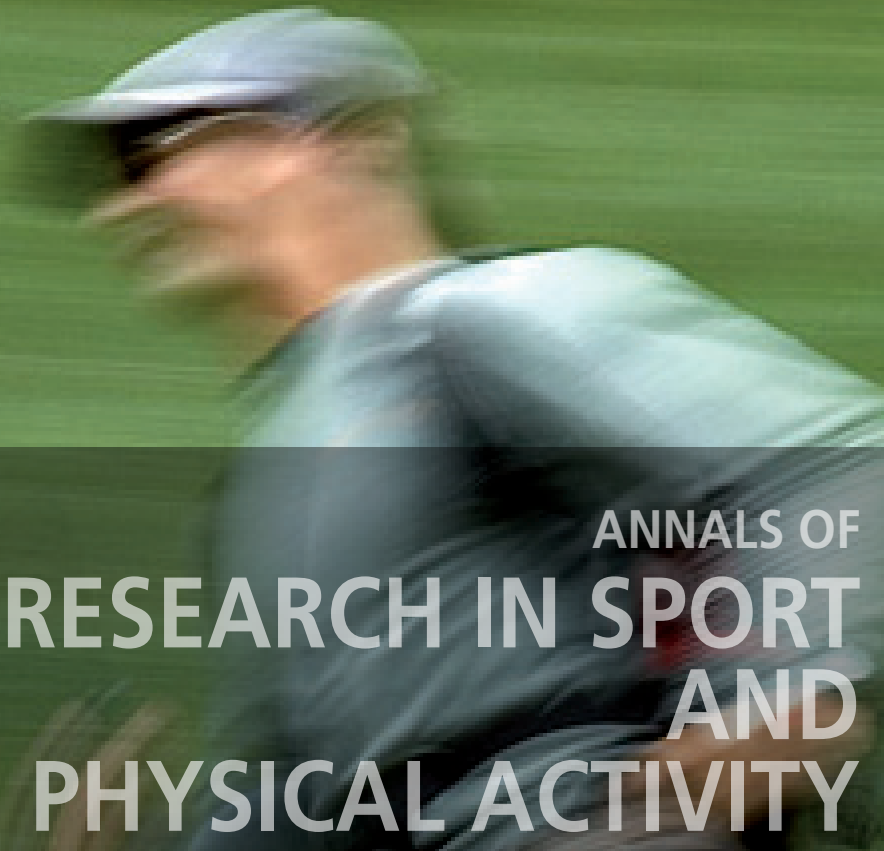

FACULDADE DE

CIÊNCIAS DO

DESPORTO E

EDUCAÇÃO FÍSICA DA UNIVERSIDADE DE COIMBRA

IMPRENSA

DA UNIVERISDADE

DE COIMBRA 
2・SPORT TRAINING

FOOTBALL INJURIES DURING SERIE A SEASON 2009/2010 
F.M. Francioni ${ }^{1}$, A. Tessitore.

\section{PURPOSE}

The present study aimed to analyze the incidence of football injuries in the most important Italian championship.

\section{METHODS}

Injuries were considered when causing an absence from a match during 380 football matches of Serie A during 2009/2010. All 736 players selected by the team to participate in the tournament were included in the study. Players were divided in three group based on the transfer's date: players in the same club during the season 2008/09 (SC), players that changed club before the first training of new team (NCB) and players moved in the new team after the first training (FNT). Players were divided in five age categories: <18years (IA, $n=4 ; 1$ injury),19-21 (IIA, $n=144 ; 3$ injuries), 22-25years (IIIA, $n=149 ; 84$ injuries), 26-29years (IVA, $n=204,131$ injuries), >30years (VA, $n=235 ; 168$ injuries).

\section{RESULTS}

More absences for injury were found in FNT group (474 incidence $=45788$ minutes) while SC was the group with less injury (1737 incidence $=167505$ minute). More absences for injury were found in the VA group while IIA was the group with less injury

\section{CONCLUSIONS}

Transfer date is a factor influencing the incidence of injuries in Football. However, the football club continues the recruitment after the beginning of preseason.

\footnotetext{
1 University of Rome "Foro Italico", Italy;e-mail: fmfrancioni@hotmail.it.
} 